\title{
Retraction
}

\section{Retracted: Therapeutic Management of the Hallux Rigidus}

\section{Rehabilitation Research and Practice}

Received 18 May 2014; Accepted 18 May 2014; Published 21 May 2014

Copyright (C) 2014 Rehabilitation Research and Practice. This is an open access article distributed under the Creative Commons Attribution License, which permits unrestricted use, distribution, and reproduction in any medium, provided the original work is properly cited.

The paper titled "Therapeutic Management of the Hallux Rigidus" [1], published in Rehabilitation Research and Practice, has been retracted as it was found to contain substantial flaws in its scientific methodology.

\section{References}

[1] A. Aggarwal, S. Kumar, and R. Kumar, "Therapeutic management of the hallux rigidus," Rehabilitation Research and Practice, vol. 2012, Article ID 479046, 9 pages, 2012. 